\title{
Major components in oils obtained from Amazonian palm fruits
}

\author{
By M.F.G. Santos ${ }^{a}$, S. Marmesat ${ }^{b}$, E.S. Brito ${ }^{c}$, R.E. Alves ${ }^{d}$ and M.C. Dobarganes ${ }^{b, *}$ \\ ${ }^{a}$ Instituto de Pesquisas Científicas e Tecnológicas de Amapá-IEPA. Rodovia JK, Km 10, \\ 68900-000, Macapá-AP, Brasil \\ ${ }^{\mathrm{b}}$ Instituto de la Grasa-CSIC. Avda. Padre García Tejero, 4, 41012 Sevilla-Spain \\ ${ }^{\circ}$ Embrapa Agroindústria Tropical. Rua Dra. Sara Mesquita, 2270, Pici, 60511-110, Fortaleza-CE, Brasil \\ ${ }^{\mathrm{d}}$ Programa de Pós-Graduação em Agronomia-PPGA/UFPB. Rodovia PB 079, Km 12, \\ 58397-000, Areia-PB, Brasil \\ *Corresponding author: cdobar@ig.csic.es
}

\begin{abstract}
RESUMEN
Componentes mayoritarios de aceites obtenidos de frutos de palmeras de la región amazónica

Las palmeras nativas de la familia Arecaceae constituyen recursos alimentarios de gran importancia en la región amazónica. A pesar de su diversidad y utilidad, muchas especies son poco conocidas por lo que son de interés los estudios dirigidos a conocer la calidad y composición de las especies menos exploradas para evaluar su potencial económico.

El objetivo de este estudio fue la caracterización de los aceites obtenidos del mesocarpio de frutos de especies de bacaba (Oenocarpus bacaba), buriti (Mauritia flexuosa), inajá (Maximiliana maripa), pupunha (Bactris gasipaes) y tucumã (Astrocaryum vulgare), de importante producción en el Estado de Amapá, Brasil. Se analizaron sus características físicoquímicas, composición de ácidos grasos y composición de triglicéridos (TAG) mediante cromatografías líquida y de gases. Se determinó igualmente la composición proximal de los mesocarpios de los frutos.

Los resultados indicaron que los aceites obtenidos eran todos de buena calidad. Por otra parte, el ácido oleico, entre 39.2 y $71.6 \%$, y el ácido palmítico, entre 20.8 y $39.6 \%$, fueron los dos ácidos mayoritarios en todos los aceites. El aceite de inajá fue el único con cantidades significativas de ácido laurico $(4.6 \%)$ y mirístico $(10.7 \%)$ ya que los demás contenían sólo ácidos grasos de 16 y 18 átomos de carbono. De acuerdo con su composición, las especies mayoritarias de TAG en todas las muestras fueron POP, POO y OOO. Finalmente, el contenido en aceite de los frutos fue elevado, oscilando entre $17.0 \%$ en la especie de pupunha hasta el $38.3 \%$ en la de bacaba, expresados sobre base seca.
\end{abstract}

PALABRAS CLAVE: Aceites vegetables - Ácidos grasos - Amazonia - Frutos de palmeras - Triglicéridos.

\section{SUMMARY}

Major components in oils obtained from Amazonian palm fruits

Native palm trees belong to the Arecaceae family and are among the most useful plant resources in the Amazons. Despite its great diversity and various uses, few species have been study in detail, which makes it necessary to perform more comprehensive studies on the quality and composition of species not yet explored.
This study deals with the characterization of the major compounds in the oils obtained from the mesocarp of fruits of the main palm species from the State of Amapá, Brasil, i.e. bacaba (Oenocarpus bacaba), buriti (Mauritia flexuosa), inajá (Maximiliana maripa), pupunha (Bactris gasipaes) and tucumã (Astrocaryum vulgare). Physicochemical characteristics, fatty acids and triacylglycerol (TAG) contents were analyzed by HPLC and GC. The proximate composition of the fruits was also analyzed.

The results relating to acidity, peroxide value and polar compounds indicate good quality of the oils obtained. Oleic acid ranging from 39.2 to $71.6 \%$ and palmitic acid ranging from 20.8 to $39.6 \%$ were the two major fatty acids in all the samples. The oils from inajá were characterized by the presence of significant amounts of lauric (4.6\%) and miristic (10.7\%) acids while in bacaba, buriti, pupunha and tucumã, as in most edible vegetable oils, only the fatty acids of 16 and 18 carbon atoms were present. Accordingly, the major TAG species in all the samples were POP, POO and OOO. The mesocarp of the palm fruit had a high content in lipids ranging from $17.0 \%$ for pupunha to $38.3 \%$ for bacaba, expressed as dry basis.

KEY-WORDS: Amazonian - Fatty acids - Palm fruits Triacylglycerols - Vegetable oils.

\section{INTRODUCTION}

Native palm trees belong to the Arecaceae family and are among the most useful plant resources in the Amazon. Some species have palm fruits with high contents in oil either in the mesocarp, in the kernel or in both (Clement et al., 2005), and constitute one of the main sources of oils and fats with applications in food, pharmaceutical, cosmetic and other industries. Despite their great diversity and numerous applications, few species have been exploited, making it necessary to perform more comprehensive studies on the quality and composition of species not yet explored.

Previous studies focusing on different species have shown that their fruits are of great potential interest due to their high lipid content and specific composition. The major fatty acids are mainly unsaturated oleic acid (Mambrín and Barrera Arellano, 1997; Escriche et al., 1999; Yuyama et al., 2003; Montúfar et al., 2010;) and among minor 
compounds, carotenoids, sterols and tocopherols stand out (Bereau et al., 2003; Rosso and Mercadante, 2007; Rodrigues et al., 2010; VázquezOcmín et al., 2010). Consequently, palm fruits are not only alternative foods for the population of the region, but they could be a source of high-quality vegetable oils, giving a high added value to the fruit.

The aim of this study was to characterize the oils obtained from the fruits of the main palms from the State of Amapá, Brazil, such as bacaba (Oenocarpus bacaba), buriti (Mauritia flexuosa), inajá (Maximiliana maripa), pupunha (Bactris gasipaes) and tucumã (Astrocaryum vulgare). In this paper, the physicochemical characteristics and major compounds such as fatty acids and TAG species are also analyzed.

\section{EXPERIMENTAL PART}

\subsection{Materials}

Samples of fruits from five palm species, i.e. bacaba (Oenocarpus bacaba), buriti (Mauritia flexuosa), inajá (Maximiliana maripa), pupunha (Bactris gasipaes) and tucumã (Astrocaryum vulgare), were collected in the State of Amapá, Brazil. The mesocarp of the fruits was separated, moisture was eliminated by freeze-drying before lipid extraction and lyophilized samples were maintained at $-30^{\circ} \mathrm{C}$ until extraction and analysis.

\subsection{Lipid extraction}

The total amount of lipids in the samples was obtained by Soxhlet applying an extraction period of $6 \mathrm{~h}$ and diethyl ether as solvent (AENOR, 1991). Then, the solvent was evaporated under vacuum and the extracted oil was dried to constant weight using a stream of nitrogen.

\subsection{Analytical determinations}

\subsubsection{Triacylglycerol composition}

\subsubsection{GC analysis}

TAG species were determined by GC using an Agilent 6890 chromatographer (Palo Alto, CA) equipped with a split/split-less injector, a Quadrex Aluminum-Clad 400-65HT capillary column (30 m length, $0.25 \mathrm{~mm}$ i.d., $0.1 \mu \mathrm{m}$ film thickness; Woodbridge, CT) and an FID. Hydrogen was used as carrier gas (Fernández-Moya et al., 2000). The injector and detector temperatures were 360 and $370^{\circ} \mathrm{C}$, respectively, the oven temperature was maintained at $335^{\circ} \mathrm{C}$, and a head pressure gradient from 100 to $180 \mathrm{kPa}$ was applied. A linear gas rate of $50 \mathrm{~cm} \mathrm{~s}^{-1}$ and a split ratio of 1:80 were used. One microliter of a solution of oil in acetone $\left(5 \mathrm{mg} \mathrm{mL}^{-1}\right)$ was injected. The TAG species were identified and the data corrected for the relative response of the FID (Carelli and Cert, 1993).

\subsubsection{HPLC analysis}

The HPLC separations were done on a LiChrospher 100 RP-18 (5 $\mu \mathrm{m})$ column $(25 \mathrm{~cm} \times$ $4 \mathrm{~mm}$ I.D.) using an HP 1050 gradient pumping unit (Hewlett-Packard, Avondale, PA, USA). Using RI detection, an HP 1047A detector and a mobile phase of acetone-acetonitrile (1:1) at a flowrate of $1.15 \mathrm{~mL} \mathrm{~min} \mathrm{mer}^{-1}$ were used. Ten microliters of a solution of oil in acetone $\left(50 \mathrm{mg} \mathrm{mL}^{-1}\right)$ were injected. For quantitative results, response factors were applied (Moreda et al., 2003).

\subsubsection{Fatty acid composition}

Fatty acid composition was determined by GC after derivatization of the oils to FAME with $2 \mathrm{~N} \mathrm{KOH}$ in methanol, according to the IUPAC Standard Method (IUPAC, 1992a; 1992b). An Agilent 6890 gas chromatography system (Palo Alto, CA) equipped with a split/split-less injector, an Innowax capillary column (30 m length, $0.25 \mathrm{~mm}$ i.d., 0.20 $\mu \mathrm{m}$ film thickness) and a flame ionization detector (FID) was used. Hydrogen was used as carrier gas. The detector and injector temperatures were $250^{\circ} \mathrm{C}$. The initial oven temperature was $180^{\circ} \mathrm{C}$ and a temperature gradient from 180 to $220^{\circ} \mathrm{C}$ at $3^{\circ} \mathrm{C} \mathrm{min}^{-1}$ was applied. Injections were performed using a split ratio of 1:50.

\subsubsection{Other determinations}

The following AOCS Official Methods (AOCS, 1997) were used to characterize the samples: Free Fatty Acids (AOCS Method Ca 5a-40), Peroxide Value (AOCS Method Cd 8b-90) Oxidative Stability (AOCS Method Cd 12b-92), using Rancimat equipment at $100^{\circ} \mathrm{C}$ ) and Unsaponifiable Matter (AOCS Method Ca 6a-40). Polar compounds were determined according to the IUPAC Standard Method (IUPAC, 1992c)

\section{RESULTS AND DISCUSSION}

Table 1 shows the proximate composition of the mesocarp of the palm fruits. Results are the average of two determinations. As can be observed, the oil contents range from $5.9 \%$ for pupunha to $22.1 \%$ for bacaba, on a wet basis. Results were also expressed on a dry basis (between brackets in Table 1) for direct comparison with those found in previous references. Thus, the values found were similar to those reported by Rodrigues et al. (2010) for inajá (35.5\%) and lower for buriti and tucumã (38.4 y $38.5 \%$, respectively). However, the oil contents found for bacaba and pupunha were higher than those reported by Mambrín y Barrera-Arellano (1997) and Yuyama et al. (2003) for bacaba (24.8\%) and pupunha (7.7-11.1\%), respectively.

The physicochemical characteristics of the five oils are shown in Table 2. Concerning the 
indexes commonly used to evaluate the initial quality of vegetable oils, i.e., free acidity, PV, and unsaponifiable matter, values were found within the expected ranges for crude oils of good quality. For example, the regulation for virgin olive oil establishes a maximum of $2 \%$ for free fatty acids and 20 meq $\mathrm{O}_{2} \mathrm{~kg}^{-1}$ and, as can be observed, these values were only overpassed for free fatty acid content in bacaba. Values for the oil stability index (OSI), which provides an estimation of oil shelf-life were highly variable, ranging from 6.3 to $34.2 \mathrm{~h}$ at $100^{\circ} \mathrm{C}$. The distinct values of $\mathrm{OSI}$, found for the five oils can be attributed to differences in the degree of unsaturation and antioxidant content and will be commented later.
The quantification of polar compounds gives a direct evaluation of all the compounds having polarity higher than that of TAG, the major compounds in edible fats and oils. The values found, between 3.3 and $5.2 \%$, were low as percentages below $5-6 \%$ are indicative of good quality oils even for refined oils when free fatty acids have been eliminated (Lumley, 1988). Consequently, all the oils analyzed had a good initial quality.

The fatty acid composition of the five palm oils is given in Table 3 . As can be observed, the content in unsaturated fatty acids was around $70 \%$ for bacaba, buriti and tucumã, oils characterized by a high nutritional value, similar stability against

Table1

Proximate composition (\%) of the mesocarp of Amazonian palm fruits

\begin{tabular}{lccccc}
\hline \multirow{2}{*}{\multicolumn{1}{c}{ Analysis }} & \multicolumn{5}{c}{ Palm Species } \\
\cline { 2 - 6 } & Bacaba & Buriti & Inajá & Pupunha & Tucumã \\
\hline Moisture & 42.4 & 62.4 & 58.5 & 65.1 & 55.5 \\
Lipids & 22.1 & 10.6 & 14.6 & 5.9 & 11.8 \\
& $(38.3)^{\star}$ & $(28.3)^{\star}$ & $(35.2)^{\star}$ & $(17.0)^{\star}$ & $(26.6)^{\star}$ \\
Defatted dry matter & 35.5 & 27.0 & 26.9 & 29.0 & 32.7 \\
\hline
\end{tabular}

* \% lipids on a dry basis

Table 2

Physicochemical characteristics of oils extracted from the mesocarp of Amazonian palm fruits

\begin{tabular}{lccccc}
\hline \multirow{2}{*}{ Analysis } & \multicolumn{5}{c}{ Palm Species } \\
\cline { 2 - 6 } & Bacaba & Buriti & Inajá & Pupunha & Tucumã \\
\hline Free fatty acids (\%) & 2.4 & 1.5 & 1.0 & 2.0 & 1.9 \\
Peroxide value (meq $\mathbf{O}_{\mathbf{2}} \mathbf{~ k g}^{-1}$ ) & 11.9 & 7.4 & 6.5 & 6.4 & 6.8 \\
Oil stability index (h, $\left.\mathbf{1 0 0}^{\circ} \mathbf{C}\right)$ & 11.9 & 16.9 & 6.3 & 34.2 & 10.1 \\
Unsaponifiable matter (\%) & 1.0 & 1.3 & 0.8 & 1.3 & 1.8 \\
Polar compounds (\%) & 5.0 & 3.3 & 3.7 & 3.6 & 5.2 \\
\hline
\end{tabular}

Table 3

Fatty acid composition (\%) of oils from the mesocarp of Amazonian palm fruits

\begin{tabular}{lccccc}
\hline \multirow{2}{*}{ Fatty acid } & \multicolumn{5}{c}{ Palm Species } \\
\cline { 2 - 6 } & Bacaba & Buriti & \multicolumn{1}{c}{ Inajá } & Pupunha & Tucumã \\
\hline C12:0 & $-^{*}$ & - & $4.6 \pm 0.5$ & - & - \\
C14:0 & - & - & $10.7 \pm 0.4$ & - & - \\
C16:0 & $25.9 \pm 0.5$ & $20.8 \pm 2.3$ & $25.1 \pm 2.3$ & $39.6 \pm 1.1$ & $23.4 \pm 0.2$ \\
C16:1 & $1.1 \pm 0.1$ & - & $0.3 \pm 0.1$ & $5.2 \pm 0.1$ & - \\
C18:0 & $4.7 \pm 0.2$ & $1.6 \pm 0.1$ & $1.6 \pm 0.1$ & $1.7 \pm 0.0$ & $2.6 \pm 0.1$ \\
C18:1 & $46.2 \pm 0.5$ & $71.6 \pm 2.1$ & $39.2 \pm 1.0$ & $46.2 \pm 1.3$ & $64.7 \pm 1.0$ \\
C18:2 & $20.0 \pm 0.2$ & $2.5 \pm 0.1$ & $12.9 \pm 0.6$ & $4.0 \pm 0.1$ & $4.1 \pm 0.2$ \\
C18:3 & $0.6 \pm 0.0$ & $1.4 \pm 0.1$ & $1.5 \pm 0.2$ & $1.3 \pm 0.1$ & $3.1 \pm 0.1$ \\
C20:1 & - & $0.7 \pm 0.1$ & $1.3 \pm 0.7$ & - & - \\
Others & $1.6 \pm 0.0$ & $1.3 \pm 0.3$ & $3.0 \pm 1.1$ & $2.0 \pm 0.7$ & $2.0 \pm 0.8$ \\
\hline
\end{tabular}

*not detected 
oxidation (see OSI values in Table 2) and liquid at room temperature. More concretely, buriti and tucumã had high contents in monounsaturated fatty acids, similar to that found for olive oil. However, inajá and pupunha are characterized by a similar and high content in saturated fatty acids, around $40 \%$. The main difference between both oils is the presence of significant amounts of lauric and miristic acid in inajá while for pupunha the main fatty acid was palmitic acid as in the case of palm olein. Fatty acid compositions were similar to those reported for bacaba and tucumã (Mambrin y Barrera-Arellano, 1997), buriti (Rodrigues et al., 2010; VásquezOcmín et al., 2010) and pupunha (Yuyama et al., 2003). For inajá, Rodrigues el al. (2010) found lower percentages for miristic and palmitic (7.6 and $20.1 \%$ ) and a significantly higher value for oleic acid $(52 \%)$. It is also interesting to observe the great differences in stability against oxidation (see OSI values in Table 2) between oils coming from inajá and pupunha in spite of their similar content in saturated fatty acids which in part is due to their different content in polyunsaturated fatty acids, which are highly susceptible to oxidation. However, the balance between antioxidant and pro-oxidant minor compounds should also play an important role, especially considering that bacaba had an even higher content in polyunsaturated fatty acids, which is compatible with a higher stability against oxidation.

A detailed study of the TAG species present in the five oils was carried out by means of HPLC and GC. No previous information was found with the exception of the analysis of bacaba (Antoniosi Filho et al., 1995) and buriti (Saraiva et al., 2009) by GC. Table 4 shows the TAG composition analyzed by HPLC. Under isocratic conditions, the retention time for the TAG species is directly proportional to the number of carbon atoms and inversely proportional to the total number of double bonds in the three fatty acyl chains. The TAG species are separated according to their equivalent carbon number $(E C N)$, which is defined by the formula: $\mathrm{ECN}=\mathrm{CN}-2 \mathrm{n}$, where $\mathrm{CN}$ is the acyl carbon number and $n$ the number of double bonds of fatty acids constituting the triacylglycerols. As can be calculated, the ECN of the identified TAG ranges from 44 to 50 . For oils mainly constituted by fatty acids of 16 and 18 carbon atoms, i.e. bacaba, buriti, pupunha and tucumã, the TAG species add up to between 91.9 and $98.7 \%$ while, in the case of inajá, only $51.7 \%$ was identified. The difficulties found for inajá are due to the exponential increase in TAG species when the number of fatty acids in the oil increases. As a consequence, firstly, there is a significant number of TAG species at low concentrations; secondly, there are an increasing number of unresolved compounds with similar or identical retention times and different molecular weights and, finally, there are also species with ECN lower than 44 eluting at high retention times such as broad peaks of difficult quantification.

A much better resolution was obtained in the analysis by GC given in Table 5 . The retention time for TAG species is directly proportional to both the

Table 4

Triacylglycerol species (\%) of oils from the mesocarp of Amazonian palm fruits determined by HPLC-RI

\begin{tabular}{lccccc}
\hline \multirow{2}{*}{ TAG species } & \multicolumn{5}{c}{ Palm Species } \\
\cline { 2 - 6 } OLL & Bacaba & Buriti & Inajá & Pupunha & Tucumã \\
OOLn & 3.6 & 2.1 & $-{ }^{*}$ & - & - \\
PLL & 0.8 & - & - & - & 3.5 \\
POLn & 4.7 & 1.4 & - & - & 3.8 \\
OOL & 0.9 & - & - & 2.1 & - \\
POL & 9.8 & 2.5 & - & 2.6 & 5.6 \\
PoOP & 17.4 & 2.2 & 7.8 & 4.7 & 5.6 \\
PLP & 0.9 & - & - & 8.3 & - \\
OOO & 7.4 & - & 3.5 & 3.3 & - \\
SOL & 11.5 & 39.8 & 13.9 & 10.8 & 28.9 \\
POO+PLS & 3.3 & - & - & - & - \\
POP & 18.7 & 35.9 & 14.5 & 29.7 & 35.9 \\
SOO & 11.1 & 10.2 & 10 & 28.9 & 8.6 \\
POS+SLS & 2.1 & 3.2 & 1 & 1 & - \\
Others & 3.4 & 1.4 & 1.1 & 1.9 & - \\
\hline
\end{tabular}

*not detected 
number of carbon atoms and the total number of double bonds in the three fatty acyl chains. As can be observed, the number of TAG species identified was higher than $94 \%$ for all the oils. Given the high contents in oleic and palmitic acids, which are the two major fatty acids in all the samples, TAG species combining both acids, i.e. POP, POO and OOO, were the mayor species in the oils analyzed. As expected, the main difference with TAG composition obtained by HPLC (Table 4) was found for inajá as there is no overlapping of compounds differing in molecular weight due to the basis of separation. Typical gas chromatograms are shown in Figure 1, where the excellent separation among groups of compounds differing in the number of carbon atoms can be observed as well as the quantitative importance of TAG species combining oleic and palmitic acids.

Table 5

Triacylglycerol species (\%) of oils from the mesocarp of Amazonian palm fruits determined by GC-FID

\begin{tabular}{|c|c|c|c|c|c|}
\hline \multirow{2}{*}{ TAG species } & \multicolumn{5}{|c|}{ Palm Species } \\
\hline & Bacaba & Buriti & Inajá & Pupunha & Tucumã \\
\hline LaLaP & $-^{*}$ & - & 0.4 & - & - \\
\hline LaMP & - & - & 0.9 & - & - \\
\hline LaOLa & - & - & 0.8 & - & - \\
\hline LaPP & - & - & 1.2 & - & - \\
\hline LaOM & - & - & 3.2 & - & - \\
\hline LaLM & - & - & 1.5 & - & - \\
\hline MPP & - & - & 1.9 & - & - \\
\hline MOM+ LaOP & - & - & 7.9 & - & - \\
\hline MLM & - & - & 3.3 & - & - \\
\hline PPP & 0.9 & - & 1.6 & 3.1 & 1.8 \\
\hline MOP & - & - & 10.4 & - & - \\
\hline MLP + LaOO & - & - & 6.7 & - & - \\
\hline LaOL & - & - & 1.8 & - & - \\
\hline PPoP & - & - & - & 3.7 & - \\
\hline POP & 10.3 & 9.4 & 11.5 & 32.4 & 22.5 \\
\hline POPo & - & - & - & 12.2 & - \\
\hline PLP & 8.3 & - & 5.7 & - & 1.1 \\
\hline MOO & - & - & 3.9 & - & - \\
\hline MOL & - & - & 3.5 & - & - \\
\hline POS & 3.1 & 1.3 & - & 2.1 & 3.4 \\
\hline POO & 19.0 & 38.8 & 12.5 & 28.5 & 38.8 \\
\hline PLS & 4.0 & - & 0.9 & 1.6 & 1.2 \\
\hline POL & 17.7 & 2.5 & 6.2 & 6.6 & - \\
\hline PLL & 5.9 & 0.6 & 1.6 & - & 3.3 \\
\hline soo & 2.4 & 3.5 & 0.8 & 1.1 & 3.3 \\
\hline 000 & 9.3 & 35.6 & 3.9 & 6.1 & 19.4 \\
\hline SOL & 4.0 & 2.3 & - & - & 1.1 \\
\hline OOL & 8.0 & 1.7 & 2.1 & 0.8 & - \\
\hline SLL & 2.1 & - & - & - & 2.4 \\
\hline OLL & 2.8 & - & - & - & - \\
\hline Others & 2.2 & 4.5 & 5.6 & 5.5 & 2.8 \\
\hline
\end{tabular}

*not detected 
Table 6

Summary of triacylglycerol (TAG) species present in oils from the mesocarp of Amazonian palm fruits

\begin{tabular}{cccc}
\hline ECN & TAG species & NCA & TAG species \\
\hline 40 & LaLM, LaOLa, LaLaP & 40 & LaLaP \\
42 & LLL, MLL, MLM, LaOM, LaLP, LaMP & 42 & LaMP*, LaOLa, LaLLa \\
44 & OLL*, PLL, PLP, MOM, MLP, MOL, LaOO, & 44 & LaPP, LaOM, LaLM \\
& OOLn, POLn & & MPP, MOM, LaOP, LaLP, MLM \\
46 & OOL, POL, SLL, MOP, MOO, PoOP, PoOO, & 46 & \\
48 & OOO, POO, PLP, POP, PPP, SOL, PLS, MOS & 48 & PPP, MOP, MLP, PPoP, LaOO, LaOL \\
50 & SOO, POS, SLS & 50 & POP, PLP, PoOP, MOS, MOO, MOL, MLL \\
52 & SOS & 52 & POS, POO, PLS, POL, PLL, PoOO, POLn \\
54 & - & 54 & SOS, SLS, SOO, SOL, OOO, OOL, SLL, OLL, \\
\end{tabular}

* The species found in any of the oils are in bold; ECN, Equivalent carbon number; NCA, Number of carbon atoms

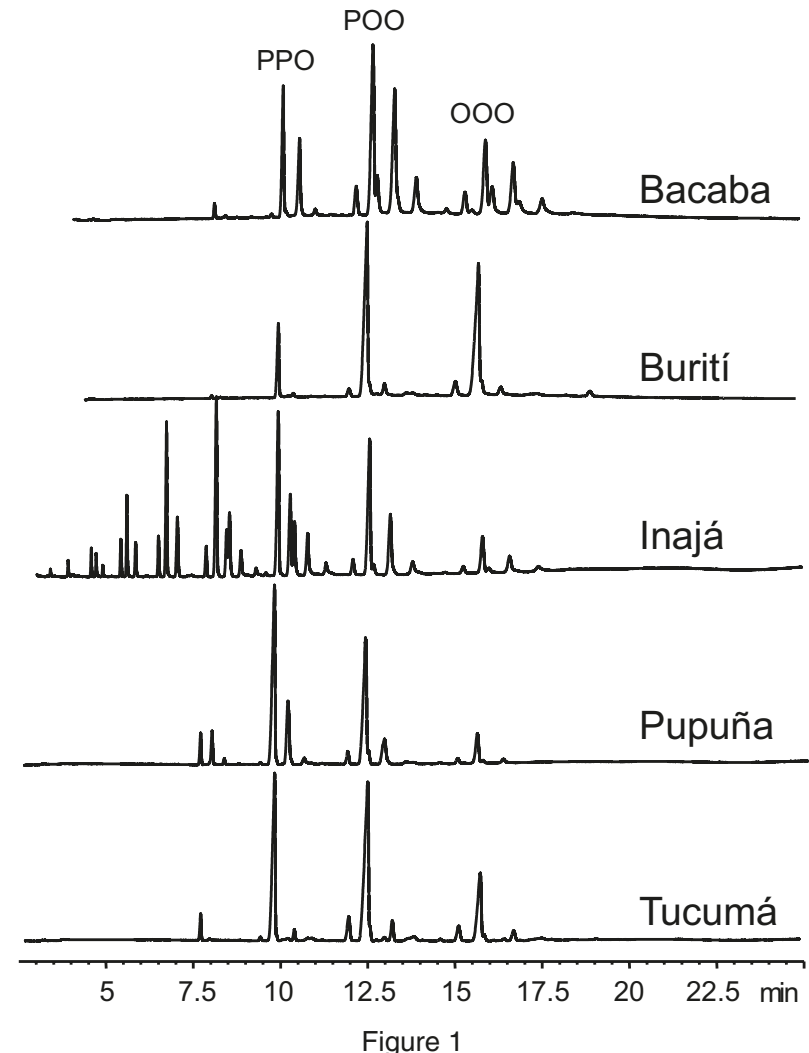

Gas chromatographic profiles of triacylglycerols of the oils from the mesocarp of fruits from Amazonian palm trees.

Finally, Table 6 summarizes all the TAG species that should be present in some of the oils analyzed taking into account the basis of separation in both analytical techniques, i.e., ECN in the analysis by HPLC and the number of carbon atoms (NCA) in the analysis by GC. The TAG species detected have been marked in bold. It can be observed that GC gave good results for practically all the species present with the exception of those expected to be at very low concentrations and it would be particularly useful for the analysis of oils with fatty acids of low molecular weight.
To sum up, from the analysis of the major components present in the oils from the Amazonian fruits it is deduced that, among those studied, two groups can be identified. Oils from inajá and pupunha contain around $40 \%$ saturated fatty acids, a composition similar to palm olein. However, oils from bacaba, buriti and tucumã had high contents in monounsaturated fatty acids and, consequently, they could be considered healthy oils, giving protection against cardiovascular diseases.

\section{ACKNOWLEDGEMENTS}

The authors thank CAPES for the doctoral fellowship conceded to M. F. G. Santos.

\section{REFERENCES}

AENOR. 1991. Asociación Española de Normalización, Catálogo de Normas UNE, Madrid.

Antoniosi-Filho NR, Mendes OL, Lanças FM. 1995. Computer prediction of triacylglycerol composition of vegetable oils by HRGC. Chromatographia 40, 557-562.

AOCS. 1997. Method Cd 12b-92 in Official methods and recommended practices of the American Oil Chemists' Society, $5^{\text {th }}$ ed., AOCS, Champaign.

Bereau D, Benjelloun-Mlayah B, Banoub J, Bravo R. 2003. FA and unsaponifiable composition of five Amazonian palm kernel oils. J. Am. Oil Chem. Soc. 80, 49-53.

Carelli AA, Cert A. 1993. Comparative study of the determination of triacylglycerols in vegetable oils using chromatographic techniques. J. Chromatogr. 630, 213-222.

Clement CR, Lleras Pérez E, Van Leeuwen J. 2005. O potencial das palmeiras tropicais no Brasil: acertos e fracassos das últimas décadas. Agrociências 9, 67-71.

Escriche I, Restrepo J, Serra JA, Herrera LF. 1999. Composition and nutritive value of Amazonian palm fruits. Food Nutr. Bull. 20, 361-365.

Fernández-Moya V, Martínez-Force E; Garces R. 2000. Identification of triacylglycerol species from highsaturated sunflower (Helianthus annuus) mutants. $J$. Agric. Food Chem. 48, 764-769. 
IUPAC. 1992a. Standard Method 2.301. Preparation of the fatty acid methyl esters. In Standard methods for the analysis of oils, fats and derivatives, 7th ed. International Union of Pure and Applied Chemistry, Blackwell Scientific: Oxford, UK.

IUPAC. 1992b. Standard Method 2.302. Gas-liquid chromatography of fatty acid methyl esters. In Standard methods for the analysis of oils, fats and derivatives, 7th ed. International Union of Pure and Applied Chemistry, Blackwell Scientific: Oxford, UK.

IUPAC. 1992c. Standard Method 2.507. Determination of polar compounds in frying fats 2.507 In Standard Methods for the Analysis of Oils, Fats and Derivatives, $7^{\text {th }}$ ed.; International Union of Pure and Applied Chemistry, Blackwell Scientific: Oxford, UK, 1992.

Lumley ID. 1998. Polar compounds in heated oils. In Frying of Foods. Principles, Changes, New Approaches. Varela G, Bender AE, Morton ID (eds) Ellis Harwood Ltd. Chichester, England.

Mambrin MCT, Barrera-Arellano D. 1997. Caracterización de aceites de frutos de palmeras de la región amazónica del Brasil. Grasas Aceites 48, 154-158.

Montúfar R, Laffargue A, Pintaud J, Hamon S, Avallone S, Dussert S. 2010. Oenocarpus bataua Mart. (Arecaceae): rediscovering a source of high oleic vegetable oil from Amazonia. J. Am. Oil Chem. Soc. 87, 167-172.

Moreda W, Pérez-Camino MC, Cert A. 2003. Improved method for the determination of triacylglycerols in olive oils by high performance liquid chromatography. Grasas Aceites. 54, 175-179.
Rodrigues AMC, Darnet S, Silva LHM. 2010. Fatty Acid profiles tocopherol of buriti (Mauritia flexuosa), patawa (Oenocarpus bataua), tucumã (Astrocaryum vulgare), mari (Poraqueiba paraensis) and inajá (Maximiliana maripa) fruits. J. Braz. Chem. Soc. 21, 2000-2004.

Rosso VV, Mercadante AZ. 2007. Identification and quantification of carotenoides, by HPLC-PDA-MS/ MS, from Amazonian fruits. J. Agric. Food Chem. 55, 5062-5072.

Saraiva S A, Cabral EC, Eberlin MN, Catharino RR. 2009. Amazonian vegetable oils and fats: fast typification and quality control via triacylglycerol (TAG) profiles from dry matrix-assisted laser desorption/ionization time-of-flight (MALDI-TOF) mass spectrometry fingerprinting. J. Agric. Food Chem. 57, 4030-4034.

Vásquez-Ocnín, P. G., Alvarado, L. F., Solís, V. C., Torres, R. P. and Mancini-Filho, J. 2010. Chemical characterization and oxidative stability of the oils from three morphotypes of Mauritia flexuosa L. f, from the Peruvian Amazon. Grasas Aceites 61, 390-397.

Yuyama LKO, Aguiar JPL, Yuyama K, Clement CR, Macedo SHM, Fávaro DIT, Afonso C, Vasconcellos MBA, Pimentel SA, Badolato ESG, Vannucchi, H. 2003. Chemical composition of the fruit mesocarp of three peach palm (Bactris gasipaes) populations grown in central Amazonia, Brazil. Int. J. Food Sci. Nutr. 54, 49-56.

Recibido: 5/2/13 Aceptado: $27 / 2 / 13$ 